\title{
Effect of Mepiquat chloride and detopping on growth and production of green gram (Vigna radiata L. Wilczek)
}

\section{Singh Gurdeep ${ }^{1}$, Kumar Kamalesh ${ }^{1}$, Singh Amanpreet ${ }^{2} \bowtie$ and Chahal Harmandeep Singh ${ }^{2}$}

Received: 27.01.2020

Revised: 12.04.2020

Accepted: 08.05.2020

\begin{abstract}
The study on "Effect of mepiquat chloride and detopping on growth and production of green gram (Vigna radiata L. Wilczek) under vertisols of Punjab" was conducted during summer season of 2017 at the Agricultural Campus for research and advanced studies in Dhablan, Punjab. The field experiment comprising 8 treatments viz., control and 7 growth retardant treatments The result revealed that the grain yield obtained with application of MC@ 250 ppm at 35 and 45 DAS (10.22 $\left.\mathrm{q} \mathrm{ha}^{-1}\right)$ was significantly higher than control $\left(6.35 \mathrm{q} \mathrm{ha}^{-1}\right)$. Various growth and yield attributes dry weight, number of pods plant ${ }^{-1}(8.12)$ number of branches plant ${ }^{-1}(9.00)$ were also significantly higher with MC @ 250 ppm (35 and 45 DAS) as compared to control. All treatments resulted in significant reduction in plant height as compare to control. The experimental results revealed that application of plant growth regulator (MC) is an effective management strategy to increase the yield of green gram crop in terms of yield
\end{abstract}

Key Words: detopping, mepiquat chloride, regulation, yield

\section{Introduction}

The green gram (Vigna radiata $\mathrm{L}$. Wilczek) is one of the most important crops in all positive aspects and is a good source of protein. The green gram is also known as the golden gram (moong), botanically belongs to the Leguminosae family and the Papilionaceae subfamily. This largely autogamous crop has practically no genetic selfincompatibility and there is no recorded evidence suggesting even the low availability of fertile pollen grains. The green gram contains 26 percent protein, 60 to 65 percent carbohydrates, 1.5 percent fat and 3.5 to 4.5 percent ash. Green-grain shells are used for fed animals. In addition, it also enriches the soil by the symbiotic fixation of nitrogen in addition to meeting more than 70 percent of its nitrogen requirements. Pulse production in India has undergone widespread improvements and changes. The best achievement in the production of legumes in the past twenty years, mainly in short-lived varieties. One of these major impacts came from growing green gram during the summer in the irrigated areas. The green gram is considered a valuable crop in relation to drought, early

\section{Author's Address}

${ }^{1}$ GSSDGS Khalsa College, Patiala, Punjab-147001

${ }^{2}$ Department of Agriculture, Khalsa College Amritsar, 143001 E-mail.: nandgharia@gmail.com maturation and rapid growth with a minimum of). required fertilizer. The green gram harvest is adjusted between the Rabi harvest and the sowing of Kharif crops for a period of three months, when the land is monitored. Plant growth regulators are used as aids to increase the yield of different crops. The application of a plant growth regulator helps to modify the physiological processes of crops in the form of growth and development. These are chemicals that are used in low concentrations to affect the growth and development of plant cells, tissues and organs. Different growth regulators used in different cultures generally signal plant growth promoters, plant growth retardants and defoliants. Plant growth retardants help reduce excessive vegetative growth and increase photosynthetic efficiency, improve the source-sink ratio and increase crop yields. Therefore, growth regulators play a diversified role in improving efficiency including photosynthetic capacity of plants and plays an important role in improving the font well relationship, thus stimulates the translocation of photoassimilates and improves crop productivity. (Dhashora and Jain, 1994; Solaimalai et al., 2001). PGR in general, increase the amount of flowers on the plant when applied to flowering stage The fall 
of flowers and pods can be reduced to to some extent by spraying various growth regulators (Ramesh and Thirumuguran, 2001), who prove that performance and quality the configuration of food pulses can be improved growth regulators application. Chemical mepiquat chloride is a plant growth retardant that helps slow the biosynthesis process of the hormone gibberellic acid in plants (Arteca, 1996). In this method, it prevents the elongation of the cell, decreases the height of the plant and increases the chlorophyll content in plants. The chemical of mepiquat chloride under such conditions decreases the height and length of the plant. Between nodes, transfer metabolites from leaves and stems to fruit development, which helps increase crop yields. The number of pods per unit area is directly linked to performance. The effect of plant growth retardants is different depending on plant species, cultivars, chemical concentration, time of application of chemicals and other practices. Mepiquat chloride reduces the height of the plant and the accumulation of dry matter. Increase the pod per plant, grain per pod, grain yield and protein content in green grams. Elimination (elimination of the apical epidemic) is another important agronomic practice which helps to overcome the apical area and, consequently, increases the number of lateral branches and the configuration of the sheath. In the summer of green gram, disarmament is known to alter the sourcesink relationship by stopping vegetative growth and accelerating the reproductive phase. It also contributes to the production of more pods bearing pods with lush foliage, which leads to an increase in photosynthetic activity, the accumulation of more photosynthesis, which ultimately results in better seed quality with a yield in higher seeds. In reported that, cutting chickpeas resulted in a significant increase in the number of productive branches, pods, seeds, weight of 100 seeds and seed yield per plant compared to the control treatment.

\section{Materials and Methods}

The experiment was conducted at field of Campus for research and advance studies in Dhablan village, Department of agronomy, G.S.S.D.G.S. Khalsa collage Patiala during 2017 to study the effect of mepiquat chloride and detopping on growth and production of green gram (Vigna radiata L.). The experiment was laid out in randomized complete block design with 8 treatments and 3 replications. The treatment were: $\mathrm{T}_{1}$ : Mepiquat chloride $200 \mathrm{ppm}$ (35 DAS), $\mathrm{T}_{2}$ : Mepiquat chloride $200 \mathrm{ppm}$ (35 and 45 DAS), T3: Mepiquat chloride 250 ppm (35 DAS), T4: Mepiquat chloride $250 \mathrm{ppm}$ (35 and $45 \mathrm{DAS}$ ), $\mathrm{T}_{5}$ : Mepiquat chloride $300 \mathrm{ppm}$ (35 DAS), $\mathrm{T}_{6}$ : Mepiquat chloride $300 \mathrm{ppm}$ (35 and $45 \mathrm{DAS}$ ), $\mathrm{T}_{7}$ : Detopping (35 DAS), $\mathrm{T}_{8}$ : Control. The physicochemical properties of surface soil were: textural class clay, soil $\mathrm{pH} 7.8$, organic carbon 0.62 percent, available nitrogen $350 \mathrm{~kg} \mathrm{ha}^{-1}$, with available $\mathrm{P}_{2} 0_{5} 24 \mathrm{~kg} \mathrm{ha}^{-1}$ and available $\mathrm{K}_{2} 0184 \mathrm{~kg}$ $\mathrm{ha}^{-1}$ (Table1). The crop was sprayed thoroughly, in such a way so that all portion of the leaf (adaxial and abasial surface) and plant parts moistened with respective solution. Spraying was done at morning hours of sunny days

Table 1: Chemical properties of the soil during experiment

\begin{tabular}{|c|c|l|}
\hline Soil property & $\begin{array}{c}\text { Soil depth, 0-15 } \\
\text { (cm) }\end{array}$ & Method employed \\
\hline $\begin{array}{c}\text { pH (1:2, soil: water } \\
\text { suspension) }\end{array}$ & 7.8 & $\begin{array}{l}\text { Beckmen's glass electrode } \\
\text { pH meter ( Jackson 1967) }\end{array}$ \\
\hline $\begin{array}{c}\text { Electrical } \\
\text { conductivity (dsm } \\
{ }^{1} \text { ) }\end{array}$ & 0.12 & $\begin{array}{l}\text { Solubridge conductivity } \\
\text { meter 1:2 soil water } \\
\text { suspension }\end{array}$ \\
\hline $\begin{array}{c}\text { Organic carbon (\%) } \\
\text { Available nitrogen } \\
\text { kg ha }{ }^{-1}\end{array}$ & 0.628 & $\begin{array}{l}\text { Walkely and Blackrapid } \\
\text { titration method (Piper 1966) }\end{array}$ \\
\hline $\begin{array}{c}\text { Available } \\
\text { phosphorus kg ha }{ }^{-1}\end{array}$ & 350.6 & $\begin{array}{l}\text { Kjeldahl method (Jackson } \\
1967)\end{array}$ \\
\hline $\begin{array}{c}\text { Available } \\
\text { potassium } \mathrm{kg} \mathrm{ha}^{-1}\end{array}$ & 24.6 & $\begin{array}{l}\text { Olsen's method (Olsen } \text { et al., } \\
\text { 1954) }\end{array}$ \\
\hline
\end{tabular}

\section{Results and Discussion \\ Plant height}

Plant height $(\mathrm{cm})$ is one of the indices for the plant growth. The data on plant height of green gram recorded at harvesting are presented in Table 2. At harvest highest plant height recorded in the treatment $\mathrm{T}_{8}$. The decrease in height may be due to the fact that Mepiquat chloride being growth retardant reduces the vegetative phase of green gram. Brar et al (1988) also reported similar results of growth regulators.

\section{Dry weight}

Dry weight (g per plant) is one of the indices for determining the growth and pysiological efficiency. The data on dry weight of green gram recorded at harvesting are presented in the Table 2. 
Effect of Mepiquat chloride and detopping

Table 2: Effect of different growth regulators on growth and yield parameters

\begin{tabular}{|c|c|c|c|c|c|c|c|c|}
\hline Treatments & $\begin{array}{c}\text { Plant } \\
\text { height }(\mathbf{c m})\end{array}$ & $\begin{array}{c}\text { Dry } \\
\text { weight } \\
\text { per plant }\end{array}$ & $\begin{array}{c}\text { No. of } \\
\text { branches }\end{array}$ & $\begin{array}{c}\text { No. of } \\
\text { pod } \\
\text { plant }^{-1}\end{array}$ & $\begin{array}{c}\text { No. of } \\
\text { seed } \\
\text { pod }^{-1}\end{array}$ & $\begin{array}{c}\text { Test } \\
\text { weight }\end{array}$ & $\begin{array}{c}\text { Grain } \\
\text { yield }\end{array}$ & $\begin{array}{c}\text { Straw } \\
\text { yield } \\
\text { (q/ha) }\end{array}$ \\
\hline $\mathrm{T} 1$ & 52.05 & 17.67 & 7.15 & 7.22 & 6.8 & 32.8 & 7.42 & 39.80 \\
\hline $\mathrm{T} 2$ & 50.20 & 17.30 & 6.60 & 7.42 & 7.3 & 32.9 & 7.65 & 38.12 \\
\hline $\mathrm{T} 3$ & 50.77 & 18.87 & 7.50 & 7.57 & 7.4 & 33.4 & 7.87 & 37.57 \\
\hline $\mathrm{T} 4$ & 48.95 & 19.35 & 9.00 & 8.12 & 8.5 & 36.6 & 10.22 & 40.12 \\
\hline $\mathrm{T} 5$ & 48.32 & 18.6 & 7.45 & 7.37 & 7.4 & 34.8 & 9.40 & 38.05 \\
\hline $\mathrm{T} 6$ & 47.50 & 16.25 & 7.65 & 7.17 & 7.2 & 33.1 & 8.52 & 39.10 \\
\hline $\mathrm{T} 7$ & 47.32 & 15.50 & 8.32 & 7.05 & 7.5 & 33.0 & 7.20 & 36.97 \\
\hline $\mathrm{T} 8$ & 53.82 & 14.65 & 6.30 & 6.67 & 6.1 & 32.0 & 6.35 & 35.52 \\
\hline CD at 5\% level & 1.19 & 1.08 & 1.09 & 1.37 & 1.46 & 1.6 & 1.16 & 1.15 \\
\hline
\end{tabular}

MC significantly influenced the total dry weight at harvest stage. MC @ 250 ppm at 35 and 45 DAS higher dry weight as compare to control which is $19.35 \mathrm{~g}$ per plant at harvest stage. The increase in dry weight in the MC treated plots could be due to increased photosynthetic ability of leafs and thus assisting in accumulation of more photosynthesis by plants and ultimately resulting in higher dry weight in plant. Similar observations earlier made by Saisankar (2001).

\section{Number of branches}

Number of branches is one of the determinant for determining the growth of plant. The data on number of branches of green gram recorded at harvesting are presented in the Table 2 and reveals that the growth regulation MC @250 ppm (35 and 45 DAS) recorded highest number of branches per plant (9.00). However control recorded least number of branches (6.30). Detopping also produce the significant effect on the number of branches. However Detopping gave at par value to the MC @ $250 \mathrm{ppm}$ (35 and 45 DAS).

\section{Number of pods plant ${ }^{-1}$}

Number of pod per plant is one of the indices of the growth of plant. The data on number of pod per plant of green gram recorded at harvesting are presented in the Table 2. Number of pods is an important yield component of green gram. Data reveal that growth regulation practices effect on total number of pods per plant. This increase may be outcome of improve the number of flowers and improved seed setting percentage. Different growth regulation practices were significantly better than control in producing more number of pods. Two sprays of MC @ 250 ppm recorded the highest number of pods per plant (21.87) and least value at control (16.40). The results lend support to the views expressed by earlier researcher (Singh et al. 2012).

\section{Number of seeds pod $^{-1}$}

Number of seed per pod is one of the indices for determining the yield of plant. The data on number of seed per pod of green gram recorded at harvesting are presented in the Table 2. Number of seeds per pod is a main yield component of crop. Much number of grains in one pod will increase the total grains per plant and due to this higher seed yield could be obtained resulting in higher economic output by applied treatments. MC @250 ppm (35 and 45 DAS) gave maximum number of seed per pod (9.45) and less number of seed per pod in control treatment. There MC @ 300 and 250 ppm gave the at par value to the best treatment.

\section{Grain yield}

Grain yield is one of the indices for determining the growth attribute of plant. The data on grain yield of green gram recorded at harvesting are presented in the Table 2 and grain yield is the most important parameter for judging the effectiveness of any applied treatment. Different growth regulation practices had a significant influence on grain yield in green gram. Two sprays of MC @ 250 ppm applied at 35 and 45 DAS recorded highest grain yield $\left(10.22 \mathrm{q} \mathrm{ha}^{-1}\right)$ which was 37.8 per cent higher than control plot (6.35 q ha $\left.{ }^{-1}\right)$ and 29.5 per cent higher than detopping treatment $\left(7.2 \mathrm{q} \mathrm{ha}^{-1}\right)$. The 
Singh et al.

increase in grain yield may be due to diversion of photosynthesis from vegetative parts to the reproductive parts i.e. a pod which ultimately leads to increase in grain yield. Higher number of pods per plant increased the grain yield of green gram. Thavaprakash et al., (2006) reported similar results in green gram that with application of putrescine and spermine an additional yield of 42 and 39 percent respectively over control.

\section{Straw yield}

Straw yield is one of the indices for determining the economic viability of plant. The data on straw yield of green gram recorded at harvesting are presented in the Table 2. Straw yield gives the estimate about the dry weight and partitioning by the crop plant. It helps to calculate the harvest index and thus economic viability of the treatments applied. As evident from data presented in Table 1. Highest straw yield was recorded high in double application MC@250 ppm at 35 and 45 DAS (40.12) and least straw yield was recorded in control (35.52). Straw yield at par when double spray MC @ 300 ppm (35 and 45 DAS) and single spray of MC @200 ppm (35 DAS).

\section{Conclusion}

The results revealed that MC had a significant effect on growth and seed yield of the crop. Hence, the importance of plant growth regulator may be utilized for effective management of natural sources in a sustainable manner. Application of plant growth regulator may be a better option, particularly in case of a short duration pulse crop like green gram.

\section{References}

Arteca, R.N. 1996. Plant Growth Substances, Principles and Applications. CBS Publisher and Distributors, New Delhi.

Brar, Z. S., Singh, M. and Singh, G. 1988. Effect of plant growth regulators on production of moongbean. Journal of Research Punjab Agriculture University(JRPAU), 25: 515-20.

Dhashora, D., and Jain P.M. 1994. Effect of growth regulators and phosphorus levels on growth and yield of soybean. Madras Agricultural Journal (MAJ), 8: 235-237

Jackson, M. L. 1967. Soil Chemical Analysis. Prentice Hall of India Pvt. Ltd. New Delhi.

Olsen, S. R., Cole, C. V., Watanabe, F. S. and Dean, L. A. 1954. Estimation of available phosphorus in soils by extraction with Sodium biocarbonate.USDA Circular (UC), 939:1-29.

Piper, C. S. 1966. Soil and Plant Analysis. Hans Publishers, Bombay, India.

Ramesh, K., and Thirumurugan V. 2001. Effect of seed pelleting and foliar nutrition on growth of soybean. Madras Agricultural Journal (MAJ), 88: 465-468.

Saisankar, S. 2001. Influence of plant growth regulators, chemicals and nutrients on productivity potential in green gram, M.Sc. Thesis submitted to University of Agriculture Science, Dharwad, Karnataka, India

Singh, G., Aggarwal, N., Ram, H. and Randhawa. 2012. Drying of foliage summer and kharif mung bean at maturity with paraquat for facilitating combine harvest. Journal of Research in Punjab Agriculture University(JRPAU), 49:216-218.

Solamani, A., Sivakumar, C., Anbumani, S., Suresh, T., and Arumugam, K. 2001. Role of plant growth regulators on rice production: Agricultural Reviews (AR), 23:33-40.

Thavaprakash, N., Velayudham, K., Djanaguiraman, M. and Prabakaran, C. 2006. Influence of plant growth promoters on assimilate partitioning and seed yield of green gram. Legume Research (LR), 29:18-24. 